\title{
EFFECT OF HIGH FAT DIET ON WEIGHT LOSS THROUGH THE EXPRESSION OF UNCOUPLE PROTEIN 1 IN MICE VISCERAL FAT
}

\author{
Indira Syahraya ${ }^{1}$, Hermina Novida ${ }^{2}$, Lilik Herawati ${ }^{3}$, Purwo Sri Rejeki ${ }^{3}$ \\ ${ }^{1}$ Universitas Airlangga, ${ }^{2}$ Department of Internal Health, ${ }^{3}$ Department of Physiology, Faculty of Medicine, \\ Universitas Airlangga, Surabaya, Indonesia
}

\section{ABSTRACT}

\begin{abstract}
Obesity has become an epidemic around the world. High fat diet (HFD) have been implemented as one of intervention to battle obesity. Uncouple protein 1 (UCP1) is one of the key factor on energy expenditure. The aim of this experiment is to see the macronutrients composition on weight loss and UCP1 expression in the visceral fat. Fifty male mice, 2-3 months old, 18-30 grams, were put in five different groups. K1 (20\% protein, $62.0 \%$ carbohydrate, $12 \%$ fat), K2 (60\% protein, $0 \%$ carbohydrate, $30 \%$ fat), K3 (45\% protein, $0 \%$ carbohydrate, $45 \%$ fat), K4 (30\% protein, $0 \%$ carbohydrate, $60 \%$ fat), K5 (15\% protein, $0 \%$ carbohydrate, $75 \%$ fat). The experiment was done in four weeks, mice body weight was measured every week. UCP1 expression seen using immunohistochemistry staining was measured at the end of the fourth week. Significant weight loss was achieved by $K 4(-9.60 \pm 3.81)$ gram by the end of week four $(p<0.05)$. K4 had the least amount of visceral fat. The result was that K4

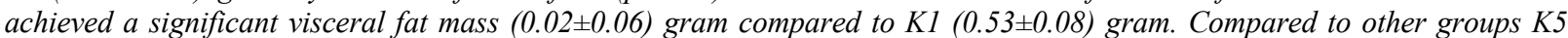
expressed UCP1 more than the others (3.78 3.72$)$ cphfp. HFD fed groups produced significant weight loss, group that had the greatest weight loss is K4. Meanwhile, each group had a variety of UCP1 expression.
\end{abstract}

Keywords: High fat diet; mice; UCP1 expression; weight loss

\section{ABSTRAK}

Obesitas telah menjadi fenomena di seluruh dunia. High Fat Diet (HFD) adalah salah satu bentuk implementasi melawan obesitas. Uncouple Protein 1 (UCP1) merupakan salah satu faktor dalam energy expenditure. Tujuan penelitian ini adalah untuk melihat komposisi makronutrien yang dapat menurunkan berat badan dan mengekspresikan UCP1 di lemak visera. Lima puluh mencit, 2-3 bulan, 18-30 gram, dikelompokkan secara acak menjadi 5 kelompok. K1 diberi pakan (20\% protein, 62.0\% karbohidrat, 12\% lemak). K2 diberi pakan (60\% protein, $0 \%$ karbohidrat, 30\% lemak). K3 diberi pakan (45\% protein, $0 \%$ karbohidrat, 45\% lemak). K4 diberi pakan (30\% protein, $0 \%$ karbohidrat, $60 \%$ lemak). K5 diberi pakan (15\% protein, 0\% karbohidrat, 75\% lemak). Penelitian dilakukan selama 4 minggu, berat badan mencit diukur tiap minggu. Ekspresi UCP1 yang dilihat melalui pewarnaan imunohistokimia dihitung pada akhir minggu ke empat. Penurunan berat badan signifikan didapat

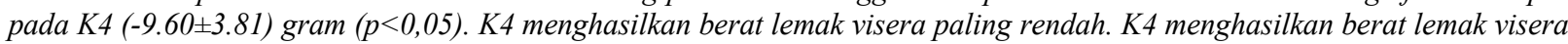

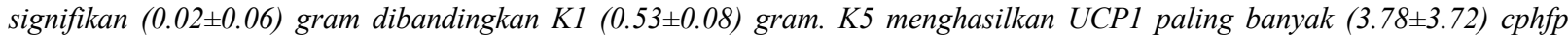
dibandingkan kelompok lain. HFD menghasilkan penurunan berat badan, kelompok yang paling banyak mengalami penurunan berat badan adalah K4. Sementara itu, hasil ekspresi UCP1 bervariasi.

Kata kunci: High fat diet; mencit; ekspresi UCP1; penurunan berat badan

Correspondence: Purwo Sri Rejeki, Department of Physiology, Faculty of Medicine, Universitas Airlangga, Jalan Mayjen Prof dr Moestopo 47, Surabaya 60131, Indonesia. E-mail: purwo-s-r@fk.unair.ac.id

- Open access under CC-BY-NC-SA license • Available at https://e-journal.unair.ac.id/FMI/

\section{INTRODUCTION}

Obesity is caused by the imbalance of calorie consumed and used, hence causing a storehouse of energy left unused and excessive body weight (Hruby \& Hu 2015). Obesity has become worldwide phenomenon and its prevalence increased every year. World Health Organization (WHO) stated that in 2016 more than one billion people across the world are suffering from overweight and 650 million people amongst them are obese. World dieticians have come out with a solution to this problem, they have created few diets to counter this problem. Among these diets are the Atkins diet, DASH diet, Mediterranean diet, and High fat diet (HFD).

The acceptable macronutrients distribution rate of fat is $20-35 \%$ of total daily calories. Diets which exceed the 
range are considered HFD. One study suggests the consumption of unsaturated fat either monounsaturated fat or polyunsaturated fat (Botchlett \& Wu 2018). Previous study which focuses in comparing high monounsaturated fatty acid (MUFA), polyunsaturated fatty acid (PUFA) and normal habitual diet showed that diet high in MUFA had benefits of weight loss (Kaippert et al 2015). The HFD was also reported to express uncouple protein 1 (UCP1) in the white adipose tissue (WAT). Previous study which used commercial HFD was able to capture the presence of multilocular UCP1 expression in the WAT (García-Ruiz et al., 2015). The UCP1 is beneficial in thermogenesis and promote energy expenditure and is used to battle obesity (Bond \& Ntambi 2018). Therefore, the aim of this experiment was to see which composition of macronutrients in HFD that is able to obtain weight loss and UCP1 expression in the visceral fat.

\section{MATERIALS AND METHODS}

\section{Ethics approval}

This experimental study was approved by the Ethical Committee of the Veterinary Faculty, Universitas Airlangga certificate number 2.KE.124.07.2018. The experiment was conducted September-October 2018 at the animal laboratory of Veterinary Faculty, Universitas Airlangga, Surabaya, Indonesia. All efforts were made to minimize suffering.

\section{Animals and weight measurement}

Fifty male mice, 2-3 months old, 18-30 grams, and are healthy physically were chosen as replication unit in this experiment. These mice were acclimated one week before the experiment begun to get used to the environment in the laboratory and was given standard diet AIN 93-M made by DYETH. These mice were then randomly allocated to five different groups. K1 the control group was given a diet with the composition of $20 \%$ protein, $62.0 \%$ carbohydrate, $12 \%$ fat. K2 was given $60 \%$ protein, $0 \%$ carbohydrate, $30 \%$ fat. K3 was given $45 \%$ protein, $0 \%$ carbohydrate, $45 \%$ fat. K4 was given $30 \%$ protein, $0 \%$ carbohydrate, $60 \%$ fat. K5 was given $15 \%$ protein, $0 \%$ carbohydrate, $75 \%$ fat. The food was given ad libitum for four weeks. Mice body weight were measured by electrical scale every week for four weeks. Mice weight was measured and the result was immediately written in a book. This routine was done for four weeks and the last body measurement was done before euthanasia on the last week.

\section{Visceral fat mass measurement}

Following euthanasia, visceral fat was dissected and was measured by electrical scale. The mice body was opened revealing the organ in which the laboratorian proceeds to take the life of the mice. Visceral fat from the abdomen: the omental, retroperitoneal, perirenal, mesenteric, and pericardial depots were dissected and measured at the end of the fourth week. All procedure was done by a team of capable laboratory technicians from the veterinary faculty.

\section{UCP1 immunohistochemistry}

After the experimental treatment, the mice were anesthesized and euthanized by dissection. The mice body were incised to get the visceral fat. The visceral fat were then stained with immunohistochemistry kit. A bs1925R UCP-1 Polyclonal Antibody by Bioss Antibodies, USA.

Uncouple protein 1 expression was identify using immunohistochemistry staining from the visceral fat (Oliveira et al 2013). UCP1 expression was captured using light microscope with power of 20 micrometer. The photos were then analyzed using a software. UCP1 expression was count using an image software Image $\mathbf{J}$ developed by Wayne Rasband.

\section{Statistical Analysis}

Data analysis was performed using Statistical Package for the Social Sciences (SPSS) program. Categorical data was presented in numbers and percentages. Numerical data was presented in the mean (standard deviation) and (standard error) if the data was normal. The one-way ANOVA test was performed to find the significance of the data. Non-parametrical test Kruskal Wallis and Mann Whitney were performed if needed. The statistical significance of differences was determined by ANOVA, Kruskal-Wallis, and Mann Whitney. $\mathrm{p}<0.05$ was considered statistically significant.

\section{RESULTS}

Fifty male mice were used in this experiment with an age range from 2-3 months, and a weight range from 18-30 grams were divided into five groups. Each group was given different kinds of diet. The approximate composition of food is given in Table 1 . There were 43 subjects who survived until the end of the experiment. 
Table 1. Composition of experimental diets (\%)

\begin{tabular}{cccc}
\hline \multirow{2}{*}{ Groups } & \multicolumn{3}{c}{ The analysis of animal fodder (\%) } \\
\cline { 2 - 4 } & Protein & Fat & Fiber \\
\hline K1 & 12.77 & 5.11 & 4.16 \\
K2 & 17.40 & 13.47 & 16.26 \\
K3 & 16.55 & 14.83 & 15.69 \\
K4 & 10.52 & 16.20 & 13.55 \\
K5 & 3.59 & 20.57 & 12.61 \\
\hline
\end{tabular}

Table 2. Changes in body weight in control group and HFD fed mice across the 4-week experiment

\begin{tabular}{ccc}
\hline & \multicolumn{2}{c}{ Mean body weight } \\
\cline { 2 - 3 } Groups & $\begin{array}{c}\text { Pre-intervention } \\
(\mathrm{g}) \pm \text { SD }\end{array}$ & $\begin{array}{c}\text { Post-intervention } \\
(\mathrm{g}) \pm \text { SD }\end{array}$ \\
\hline K1 & $23.80 \pm 2.44$ & $26.90 \pm 4.88$ \\
K2 & $25.60 \pm 2.54$ & $19.20 \pm 3.79$ \\
K3 & $24.14 \pm 3.76$ & $14.71 \pm 3.72$ \\
K4 & $23.40 \pm 3.50$ & $13.80 \pm 1.54$ \\
K5 & $25.33 \pm 2.42$ & $16.67 \pm 2.25$ \\
\hline
\end{tabular}

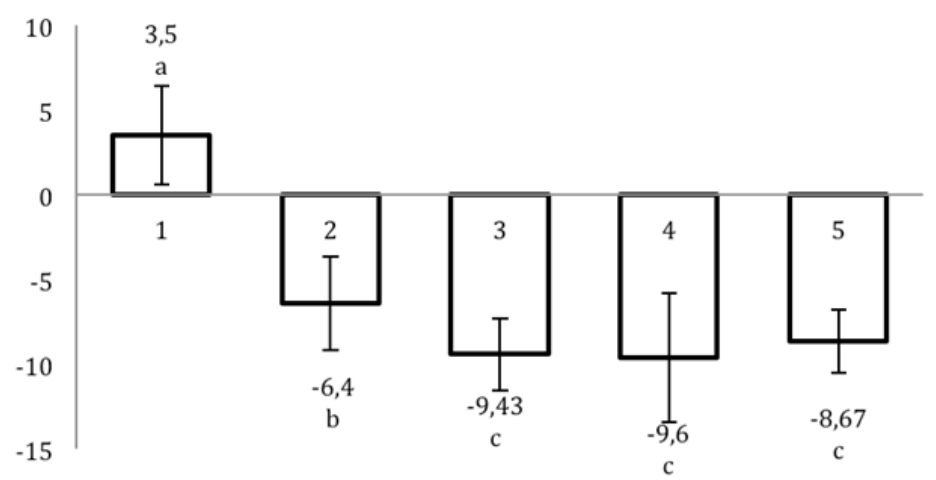

Fig. 1. Mean weight loss (g). It shows control group and HFD fed mice across the 4-week experiment. Different lower case alphabets shows significant difference $(\mathrm{p}<0.05)$ in LSD test.

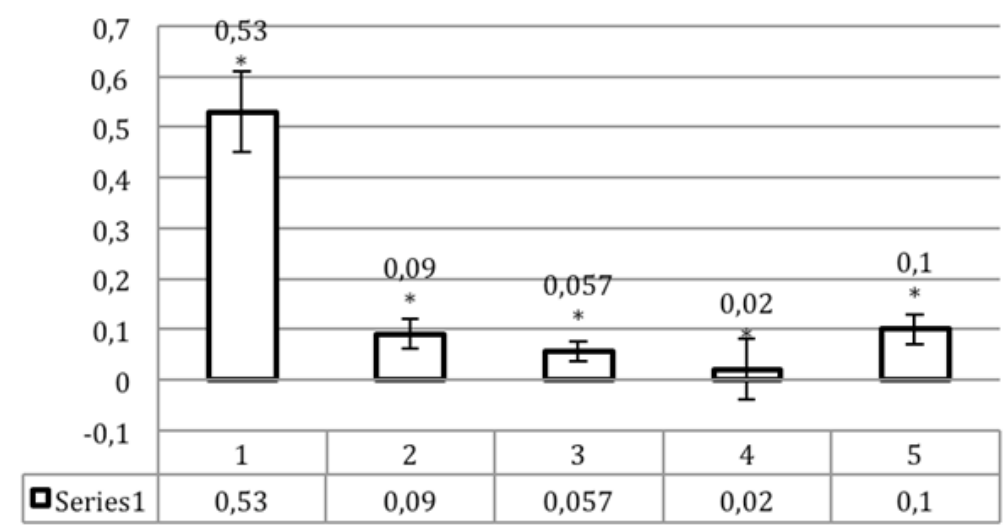

Fig. 2. Mean visceral fat mass (g). It shows control group and HFD fed mice across the 4-week experiment. The * sign shows a significant difference $(\mathrm{p}<0.05)$ in Mann-Whitney test. 


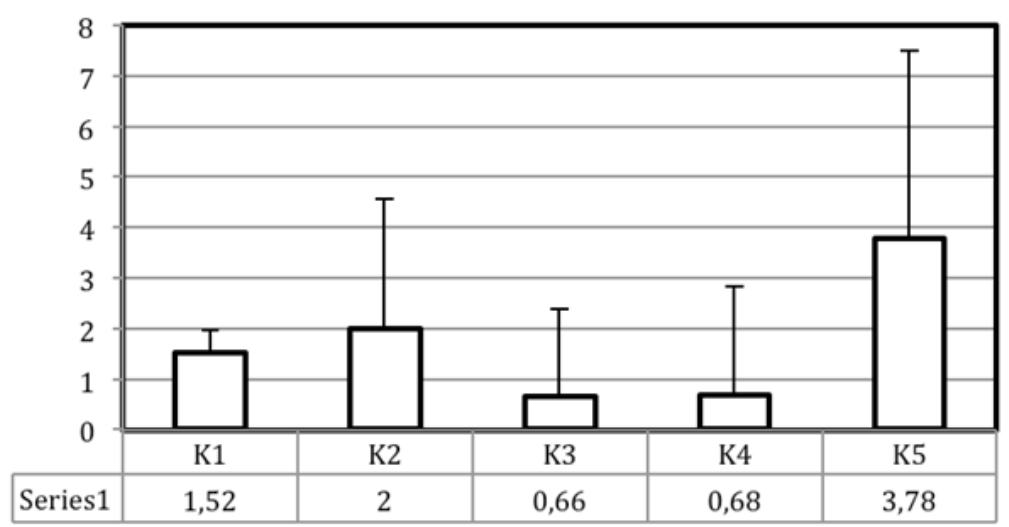

Fig. 3. Mean UCP1 expression (cphfp). It shows control group and HFD fed mice across the 4-week experiment. $\mathrm{CPHFP}=$ cell per high power field.
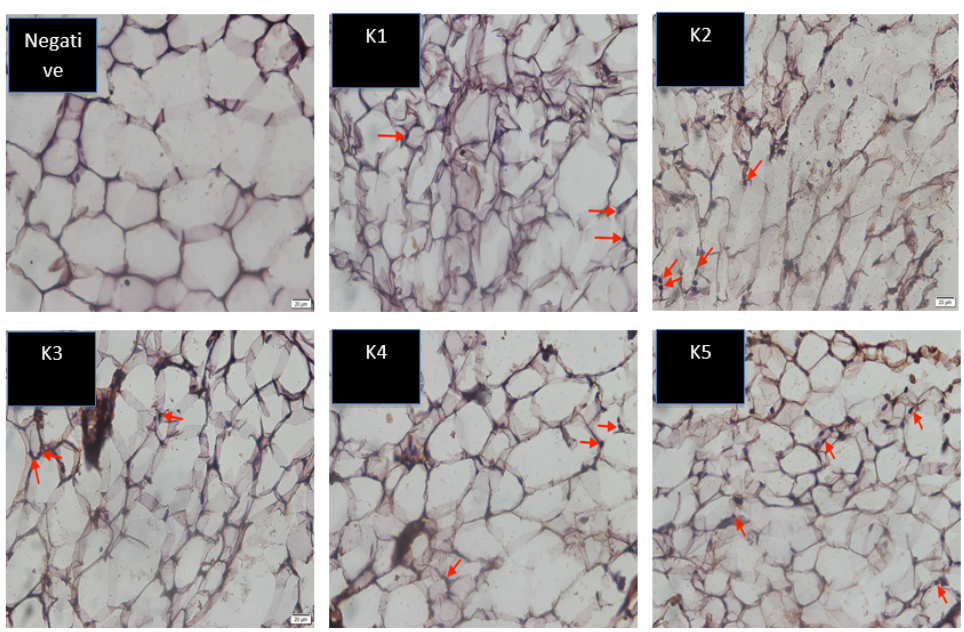

Fig. 4. UCP1 expression in immunohistochemistry staining. The red arrow shows the UCP1 expression. Taken on light microscope $20 \mu \mathrm{m}$.

We measured the body weight baseline of the mice and body weight after the intervention which could be seen in Table 2. The effect of HFD on mice body weight (grams) revealed a significant mean weight loss $(\mathrm{p}<0.05)$ compared to the control group. Among them, the group that had the most amount of weight loss was K4 followed by K3. Mean weight loss can be seen in Figure 1. Our study showed that the group who had the least amount of visceral fat amongst other was K4. HFD fed mice had significant difference of visceral fat mass $(p<0.05)$ compared to the control group. Mean visceral fat mass is shown on Fig. 2.

HFD diet also revealed to have expressed UCP1. The group that had the most amount of UCP1 expression was K5, the result showed significance $(p>0.05)$. Mean UCP1 expression is shown on Fig. 3. The immunohisto- chemistry staining will leave the expressed UCP1 as dark blue/black stain in a cell as seen in Fig. 4 .

\section{DISCUSSION}

Our study in mice shows that a nutritional intervention, such as HFD can reduce body weight. The minimum amount of visceral fat left at the end of the experiment is also noteworthy. We also found that HFD can express UCP1 in the visceral fat, however the result is variative. Consuming high fat meal was reported to decrease ghrelin hormone (Stevenson, Clevenger and Cooper, 2015). Ghrelin is a hormone that works in energy homeostasis. High ghrelin level can increase food intake and body weight, thus promotes adiposity and increases WAT (Lv et al 2018). HFD supplementation was also reported to secrete cholecystokinin (CCK), that 
responds to the intake of fat and protein. The hormone stimulates satiety after food consumption (Desai et al., 2016). The secretion CCK, which manipulates hunger, can be a tool to reduce the amount of food taken in by the body and reduce body weight, which works by preventing a positive energy balance, where the energy consumed is of greater amount compared to body metabolism and physical activity (Romieu et al 2017).

In this study the minimum amount of visceral fat is thought to promote better metabolic factors (Choe et al., 2016). Visceral fat itself is a pro inflammatory tissue, and is divided into two parts, the subcutaneous fat (SAT) and visceral fat (VAT) (Shah et al 2014). Visceral fat is considered not healthy as it trigger metabolic issues, one of them being cardiometabolic factors as it increases triglyeride and decreases HDL (Sasai et al 2015). Accumulation of triglyeride causes an increase of cell size and number and it happens primarily in the VAT (Schoettl et al 2018). It also increases inflammatory cytokine the TNFa concentration in the plasma, it can become one of the cause of obesity and other metabolic problems (Okada et al 2017). It is noted that the VAT has grater fat uptake than SAT, therefore the mobilization of VAT is instrumental for energy expenditure and can prevent accumulation of fat In this study we can prove that HFD can reduce calorie intake and induce lipolytic activity in the VAT (Hannukainen et al 2010).

The weight loss observed following HFD consumption in this study differs from previous study on this animal model. The authors reported that mice given ad libitum HFD diet increases body weight. The authors investigated the weight gain was associated with increases energy intake. The authors also found that different fat source does no significant effect on caloric intake, but mice over-ate on diet with higher total fat (Licholai et al 2018).

Contrary to our findings, one study reported a comparison of body weight, visceral fat weight, of mice fed HFD and low fat diet (LFD) for 16 weeks. The study reported that mice fed HFD had higher body weight and WAT weight compared to LFD. They also reported HFD upregulated immune and inflammatory responses. They reported that the increase of body weight and fat mass may be due to positive energy balance and low energy expenditure (Choi et al 2015).

In the present study, HFD supplementation did express UCP1 in the visceral fat, despite the variative result. Similar to our study, García-Ruiz et al (2015) presented the results of immunohistochemistry in rats fed HFD and cafeteria diet $(\mathrm{CAF})$. The author reported UCP1 expression in the retroperitoneal white adipose tissue (rWAT), in both diet.

To the best of our ability, the present study is the first to use different composition of HFD to analyze body weight, visceral fat, and UCP1 expression. One of the limitations of this study is that we did not measure feed efficiency on mice. We also did not analyze energy expenditure on mice. Another limitation is that in this mice model the UCP1 expression showed a variety of result. The minimal amount of visceral fat might not be because of UCP1 expression but other mechanism that needs further exploration.

\section{CONCLUSION}

Four weeks of HFD supplementation to mice significantly reduces body weight. Our study also informed that HFD fed mice had significant difference in visceral fat mass. HFD supplementation in mice also manage to express UCP1 in visceral fat, although the result is still variative. The UCP1 expression in HFD diet needs to be confirmed in more focused studies.

\section{ACKNOWLEDGMENT}

The authors would like to thank Universitas Airlangga for housing the experiment. We would like to thank Dr. Mohammad Anam for giving guidance to the experiment. We would also like to thank KEMENRISTEKDIKTI for funding of the experiment.

\section{REFERENCES}

Bond LM, Ntambi JM (2018). UCP1 deficiency increases adipose tissue monounsaturated fatty acid synthesis and trafficking to the liver. Journal of Lipid Research. doi: 10.1194/jlr.M078469

Choe SS, et al (2016). Adipose tissue remodeling: Its role in energy metabolism and metabolic disorders. Frontiers in Endocrinology. doi: 10.3389 /fendo.2016.00030

Choi MS, et al (2015). High-fat diet decreases energy expenditure and expression of genes controlling lipid metabolism, mitochondrial function and skeletal system development in the adipose tissue, along with increased expression of extracellular matrix remodelling- and inflamm. British Journal of Nutrition. doi: 10.1017/S0007114515000100

Desai AJ, et al (2016). Cholecystokinin-induced satiety, a key gut servomechanism that is affected by the membrane microenvironment of this receptor. 
International Journal of Obesity Supplements. doi: 10.1038/ijosup. 2016.5

García-Ruiz E, et al (2015). The intake of high-fat diets induces the acquisition of brown adipocyte gene expression features in white adipose tissue. International Journal of Obesity. doi: 10.1038/ijo.2015.112

Hannukainen JC, et al (2010). Higher free fatty acid uptake in visceral than in abdominal subcutaneous fat tissue in men. Obesity. doi: 10.1038/oby.2009.267

Hruby A, Hu FB (2015). The epidemiology of obesity: a big picture. PharmacoEconomics, 673-689. doi: 10.1007/s40273-014-0243-x

Licholai JA, et al (2018). Why do mice overeat high-fat diets? how high-fat diet alters the regulation of daily caloric intake in mice. Obesity. doi: 10.1002/oby. 22195

Lv Y, et al (2018). Ghrelin, A gastrointestinal hormone, regulates energy balance and lipid metabolism. Bioscience Reports. doi: 10.1042/BSR20181061

Okada Y, et al (2017). Comparison of visceral fat accumulation and metabolome markers among cats of varying BCS and novel classification of feline obesity and metabolic syndrome. Frontiers in Veterinary Science. doi: 10.3389/fvets.2017.00017
Oliveira AG, et al (2013). Acute exercise induces a phenotypic switch in adipose tissue macrophage polarization in diet-induced obese rats. Obesity. doi: 10.1002/oby. 20402

Romieu I, et al (2017). Energy balance and obesity: what are the main drivers?. Cancer Causes and Control. doi: 10.1007/s10552-017-0869-z

Sasai H, et al (2015). Does visceral fat estimated by dual-energy X-ray absorptiometry independently predict cardiometabolic risks in adults?. Journal of Diabetes Science and Technology. doi: $10.1177 / 1932296815577424$

Schoettl T, Fischer IP, Ussar S (2018). Heterogeneity of adipose tissue in development and metabolic function. Journal of Experimental Biology. doi: $10.1242 /$ jeb. 162958

Shah RV, et al (2014). Visceral adiposity and the risk of metabolic syndrome across body mass index: The MESA study. JACC: Cardiovascular Imaging. doi: 10.1016/j.jcmg.2014.07.017

Stevenson JL, Clevenger HC, Cooper JA (2015). Hunger and satiety responses to high-fat meals of varying fatty acid composition in women with obesity. Obesity. doi: 10.1002/oby.21202 